DOI: $10.2478 / \mathrm{v} 10014-012-0001-8$

COBISS Code 1.01

Agrovoc descriptors: phalaenopsis, orchidaceae, artificial pollination, reciprocal crossing, crossbreeding, breeding methods, plant developmental stages, varieties, germination, seeds, plant anatomy

Agris category code: F30, F50, F62

\title{
Asymbiotic seed germination of Phalenopsis Blume orchids after hand pollination
}

\author{
Helena LESAR ${ }^{1}$, Nataša ČERANIČํ, Damijana KASTELEC ${ }^{1}$, Zlata LUTHAR ${ }^{1}$
}

Received February 15, 2012; accepted February 21, 2012.

Delo je prispelo 15. februarja 2012, sprejeto 21. februarja 2012.

\begin{abstract}
Seven commercial hybrids of Phalaenopsis were included in an asymbiotic germination experiment. Plants differed in size and color of flowers and number of inflorescences and flowers. A total of 109 flowers were included of which 60 or $55 \%$ were cross-pollinated and reciprocally pollinated. Seed capsules developed on 46 (76.7\%) fertilized flowers. Of these, $38(82.6 \%)$ produced seeds as a result of 19 combinations of cross crossing and 19 combinations of reciprocal crossing. Seeds were surface sterilized using $1.6 \%$ dichloroisocyanuric acid and inoculated in Petri dishes on commercial media Sigma P1056, in two repeats. There were $23.7 \%$ contaminated Petri dishes with seeds after sterilization. The highest average percentage of protocorms $(43.1 \%)$ developed in cross crossing of plants $3 \times 7$, which statistically significantly differed ( $p<$ 0.001 ) from all other combinations of cross crossing except cross crossing $2 \times 6(30.6 \%)$. Crossing 2x6, $1 \times 6(8.1 \%)$ and $1 \times 5$ $(5.5 \%)$ overlap and there were no statistically significant differences between them. There were no statistically significant differences among all of the remaining crossings. There was an overlap of groups among combinations of cross crossing with small flowers $\mathrm{x}$ big flowers and reciprocal crossing of big flowers $x$ small flowers. In successful crossing combinations, first plants with two leaves and one or two roots developed only 80 days after seed inoculation on media. Plant no. 4 with the smallest green-yellow flowers was not compatible with any test plants. Seed capsules without seeds developed when plant 4 was a female plant and flowers just fell off when plant 4 was a male plant.
\end{abstract}

Key words: Phalaenopsis, crossing, cross crossing, reciprocal crossing, seed, media, morphological stages

\section{IZVLEČEK}

\section{ASIMBIOTSKA KALITEV ORHIDEJ Phalaenopsis Blume PO ROČNI OPRAŠITVI}

$\mathrm{V}$ poskus asimbiotske kalitve je bilo vključenih 7 komercialnih orhidej iz rodu Phalaenopsis, ki so se razlikovale po velikosti in barvi cvetov ter številu socvetij in cvetov. Skupno je bilo na njih 109 cvetov, od teh je bilo $60 \mathrm{oz}$. $55 \%$ navzkrižno in recipročno oprašenih. Semenske glavice je oblikovalo 46 oz. 76,7\% oplojenih cvetov. V 38 oz. v 82,6\% semenskih glavicah so nastala semena, kot rezultat 19 kombinacij navzkrižnega in 19 kombinacij recipročnega križanja. Semena so bila površinsko razkužena $\mathrm{z} 1,6 \%$ dikloroizocianurno kislino in inokulirana $\mathrm{v}$ dveh ponovitvah na komercialno gojišče Sigma P1056 v petrijevke. Po razkuževanju je bilo okuženih $23,7 \%$ petrijevk s semeni. Največji odstotek nastalih protokormov $(43,1 \%)$ je bil dobljen pri navzkrižnem križanju rastlin $3 \times 7$, ta odstotek se statistično značilno $(p<0.001)$ razlikuje od ostalih kombinacij navzkrižnih križanj, razen navzkrižnega križanja 2x6 $(30,6 \%)$. Križanja $2 \times 6,1 \times 6(8.1 \%)$ in $1 \times 5(5.5 \%)$ se prekrivajo in med njimi ni statistično značilnih razlik. Prav tako ni statistično značilnih razlik med ostalimi kombinacijami križanja. Med skupinami navzkrižnih križanj rastlin z malimi cvetovi $\mathrm{x}$ rastlin $\mathrm{z}$ večjimi cvetovi in recipročnih križanj rastlin $\mathrm{z}$ velikimi cvetovi $\mathrm{x}$ malimi cvetovi pride do medsebojnega prekrivanja in med njimi ni statistično značilnih razlik. Pri uspešnih kombinacijah križanj so že po 80 dneh inokulacije semen na gojišče nastajale prve rastline $\mathrm{z}$ dvema listoma in eno ali dvema koreninama. Rastlina z oznako 4 z najmanjšimi, zeleno rumenimi cvetovi ni bila kompatibilna $\mathrm{z}$ nobeno od vključenih rastlin $\mathrm{v}$ križanja. $\mathrm{V}$ primerih, ko je bila materina rastlina, so nastale semenske glavice brez semen, $\mathrm{v}$ primerih, ko je bila očetova rastlina, so cvetovi po oprašitvi odpadli.

Ključne besede: Phalaenopsis, križanje, navzkrižno, recipročno, seme, gojišče, morfološke faze

1 Department of Agronomy, Biotechnical Faculty, University of Ljubljana, Jamnikarjeva 101, SI-1000 Ljubljana, e-mail: helena.lesar@ siol.net, damijana.kastelec@uni-lj.si, zlata.luthar@bf.uni-lj.si

2 Vrhpolje 5, 6240 Kozina, e-mail: ceranic_natasa@yahoo.com 


\section{INTRODUCTION}

Phalaenopsis hybrids are a result of intensive breeding of plants of increasing market value as cut flowers and even more as potted plants. Because of the large, colorful and durable flowers, as well as their adaptability to room conditions, they are the most popular orchid genus in the horticultural industry (FloraHolland, 2010).

According to turnover data of Flora Holland flower auction Phalaenopsis were still the best-selling pot plants in Europe in 2010, as in previous years, with as many as 100 million pots sold (FloraHolland, 2010).

The Royal Horticultural Society, International Cultivar Registration Authority for Orchid Hybrids registered 643 new varieties in 2010, meaning that are altogether almost 45000 varieties of Phalaenopsis (RHS, 2010).

Orchid seeds are almost microscopic in size. Almost 400 years separate the time when orchid seeds were first seen and the development of a practical asymbiotic method for their germination by Knudson in 1921 . Thereafter, orchid growing and hybridization became widespread. Hybrids that early growers could not even have imagined became possible (Wing Yam and Arditti, 2009).

Breeding for new varieties of Phalaenopsis is lengthy and time consuming. Modern hybrid seedlings are normally derived from crosses of two high-quality parental varieties. In general, breeding programs are designed to improve the size and color of the flowers, as well as other characteristics such as longevity, stalk length, leaf shape, ease of cultivation or disease resistance (Tang and Chen, 2007).

In order to study the relationship between fertility and male or female parents used in crosses, diploid Phalaenopsis equestris was used to cross with tetraploid commercial hybrids as either male or female parents and vice versa for commercial hybrids. The fertility of each cross was determined by measuring the viable seeds produced from each cross. The results showed that 50$57 \%$ of crosses produced viable seeds if $P$. equestris was used as male parent to cross with commercial hybrids. However, no viable seed was produced if $P$. equestris was used as female parent. This means failure of seed production when tetraploid plants were used as male parents to cross with diploid varieties (Tang and Chen, 2007).

On the other hand, Hicks (2000) states that a plant with smaller flowers should be used as a female plant and a plant with larger flowers as a male plant. Pollen of smaller flowers, when germinating on stigma of a larger flower, may not develop a long enough pollen tube to reach the egg cell in the ovarium of larger flowers.

In the present study, compatibility after cross pollination and reciprocal pollination of randomly chosen commercial varieties of Phalaenopsis and the importance of the designation of female and male plant was examined, as well as the in vitro growth and development of seedlings.

\section{MATERIALS AND METHODS}

\subsection{Plant material}

Seven commercial hybrids of Phalaenopsis were included in an asymbiotic germination experiment. Plants differed in color and size of flowers and number of inflorescences and flowers (Table 1). Flowers were cross pollinated and reciprocally pollinated by hand. Some flowers were fertilized after pollination and others fell off prematurely. Fertilized flowers developed into seed capsules, with or without seeds. Those seeds were used for asymbiotic germination. Seed capsules were collected gradually as they opened at maturity. The first one was collected in 6 months and the last one in 9 months after pollination. Seeds were air dried and stored at room temperature until sterilization and inoculation on media.

Table 1: Description of Phalaenopsis hybrids used in crossing

\begin{tabular}{|l|l|l|c|c|}
\hline \multirow{2}{*}{$\begin{array}{l}\text { Plant } \\
\text { label }\end{array}$} & \multicolumn{2}{|c|}{ Flower } & \multicolumn{2}{c|}{ Number } \\
\cline { 2 - 5 } & size & color & inflorescences & flowers \\
\hline 1 & small & pink & 2 & 16 \\
\hline 2 & small & pink & 2 & 14 \\
\hline 3 & middle & purple & 2 & 15 \\
\hline 4 & smallest & green-yellow & 3 & 21 \\
\hline 5 & large & white & 1 & 9 \\
\hline 6 & large & white & 2 & 16 \\
\hline 7 & large & white & 2 & 18 \\
\hline
\end{tabular}




\section{2}

Seed was sterilized and inoculated in laminar flow on commercial media P1056 (Sigma-Aldrich, St. Loius, MO, USA) with $2.6 \mathrm{~g} / \mathrm{l}$ Gellan gum (Sigma-Aldrich) as gelling agent. The $\mathrm{pH}$ was set at 5.4 prior to autoclaving. Dichloroisocyanuric acid (Sigma-Aldrich) in a $1.6 \%$ solution was used for disinfection. Tween 20 (Sigma-Aldrich) was added for surfactant activity. Seed was transferred to microcentrifuge tubes using forceps, $0.8 \mathrm{ml}$ disinfecting solution was added and the mixture was left for 8 minutes at room temperature. Disinfection proceeded for 2 minutes in a centrifuge (J2-HS, Beckman Coulter, Brea, CA, USA) at 5000 $\mathrm{rpm}(1900 \mathrm{x} \mathrm{g})$ and $4{ }^{\circ} \mathrm{C}$. The disinfecting solution was then removed with a micropipette and sterile bi-distilled water was added. Centrifuging and washing with water was repeated four times. After one hour, the seed was inoculated on media with a micropipette, together with the last round of washing water. The seed was spread on a Petri dish containing media using a sterile glass rod which had previously been bent to a $120^{\circ}$ angle (Jevšnik, 2002). Seed of each combination of crossing was inoculated on media in two Petri dishes, i.e., in two repeats. Altogether there were 76 Petri dishes of $90 \times 15 \mathrm{~mm}$ size.

\subsection{Germination and growth}

Germination and growth took place in a growing chamber (MPC 110, IZR, Škofja Loka, Slovenia) under a $16 / 8$ photoperiod (16 hours of light, 8 hours of dark) at an illumination of $40 \mu \mathrm{mol} \mathrm{m} \mathrm{m}^{-2}$ ${ }^{1}$ and temperature of $23^{\circ} \mathrm{C}$.

\subsection{Evaluation}

Cultures were examined with a stereomicroscope (C-PS, Nikon, Tokyo, Japan) at $20 \mathrm{x}$ magnification to assess germination (swollen and not-swollen seeds) and protocorms development. The development of leaves and roots was assessed visually. Nine evaluations were performed during the experiment. The first evaluation was performed 2 days after seed inoculation on media. Others followed 6, 14, 22, 40, 50, 65,80 and 100 days after inoculation. Germinated and nongerminated seeds were counted, as well as vital protocorms with or without rhizoids and leaves and roots per square centimeter in each Petri dish.

Data were analyzed using the statistical program R ( $R$ Development Core Team, 2011). Treatments consisted of crossings: cross crossing $(\mathrm{N})$ and reciprocal crossing $(\mathrm{R})$ and of six plants: $1,2,3,5,6$ and 7: 6 cross crossings with the following combinations of plants: $\mathrm{N} 1 \times 5, \mathrm{~N} 1 \times 6, \mathrm{~N} 1 \times 7, \mathrm{~N} 2 \times 6$, $\mathrm{N} 2 \times 7, \mathrm{~N} 3 \times 7$; and 6 reciprocal crossings: R5 x 1, R6 x 1, R6 x 2, R7 x 1, R7 x 2 and R7 x 3. The treatments N2x7 and N7x2 were excluded from statistical analysis because there was no repeat evaluation. There were 12 treatments altogether of which 10 were included in statistical analysis (Figure 2).

Equality of variance among treatments was tested using Levene's test of homogeneity of variance. For the percentage of protocorms, analysis of variance of random groups was performed on transformed data $\arcsin (\operatorname{sqrt}$ (portion of protocorms))). Duncan's multiple range test was used for multiple comparison between pairs of treatments $(\alpha=0.05)$

\section{RESULTS}

\subsection{Cross and reciprocal crossing}

Table 2: Number of opened, pollinated, fertilized and detached flowers after cross and reciprocal crossing of Phalaenopsis orchids

\begin{tabular}{|c|c|c|c|c|c|c|c|c|c|c|c|c|c|c|c|c|}
\hline \multirow{2}{*}{$\begin{array}{c}\text { Plant } \\
\text { label }\end{array}$} & \multicolumn{3}{|c|}{ 1. inflorescence } & \multicolumn{3}{|c|}{ 2. inflorescence } & \multicolumn{3}{|c|}{ 3. inflorescence } & \multicolumn{5}{|c|}{ Total } \\
\hline 1 & A & B & C & D & A & B & C & D & A & B & C & D & A & B & C & D \\
\hline 2 & 8 & 6 & 5 & 1 & 7 & 6 & 4 & 2 & 0 & 0 & 0 & 0 & 16 & 12 & 9 & 3 \\
\hline 3 & 8 & 4 & 3 & 1 & 7 & 5 & 2 & 3 & 0 & 0 & 0 & 0 & 15 & 9 & 5 & 4 \\
\hline 4 & 7 & 1 & 0 & 1 & 6 & 3 & 3 & 0 & 8 & 3 & 3 & 0 & 21 & 7 & 6 & 1 \\
\hline 5 & 9 & 5 & 4 & 1 & 0 & 0 & 0 & 0 & 0 & 0 & 0 & 0 & 9 & 5 & 4 & 1 \\
\hline 6 & 8 & 4 & 3 & 1 & 8 & 4 & 4 & 0 & 0 & 0 & 0 & 0 & 16 & 8 & 7 & 1 \\
\hline 7 & 9 & 5 & 5 & 0 & 9 & 5 & 5 & 0 & 0 & 0 & 0 & 0 & 18 & 10 & 10 & 0 \\
\hline Total & 58 & 29 & 22 & 7 & 43 & 28 & 21 & 7 & 8 & 3 & 3 & 0 & 109 & 60 & 46 & 14 \\
\hline
\end{tabular}

Legend: A - opened flowers, B - pollinated flowers, C - fertilized flowers, D - detached flowers

There was a total of 109 flowers on 7 plants, 60 (55\%) of which were pollinated. We did not fertilize all the flowers per plant because the load would be too heavy.
Schwallier et al. (2011) suggest that a maximum of 3 flowers per plant or one flower per inflorescence should be pollinated. After pollination, 14 flowers (23.3\%) fell 
off prematurely. Seed capsules developed on 46 (76.7\%) of fertilized flowers. Of those, $38(82.6 \%)$ seed capsules produced seeds and $7(15.2 \%)$ seed capsules dried prematurely. One seed capsule in the combination cross crossing with plant no. 4 was empty, without seeds. In the reciprocal crossing in which plant no. 4 was the male plant, all the flowers dropped off (Table 2). A higher percentage of fallen flowers after pollination could be a consequence of plant overload, although additional fertilizers were added during capsule development.

Thirty-eight crossings produced seed capsules with germinable seeds, of which 19 were combinations of cross crossing and 19 were combinations of reciprocal crossing. Out of 7 plants included in crossing, 6 plants produced an ovule (female plants) and pollen (male plants) (Table 3).

Flowers from plant 1 were included in crossing 9 times: 4 times with plant 5, 3 times with plant 7 and 2 times with plant 6 . Plant 2 was included in crossing 5 times: 4 times with plant 6 and once with plant 7 (excluded from statistical analysis, no repetition). Plant 3 was included in crossing 5 times with plant 7 . All these combinations were successful, i.e., seeds with embryo developed in seed capsules. Seed capsules were collected when they started to open, i.e., 200 to 270 days after pollination.

Plant 4 was excluded from statistical analysis because it was not compatible in crossing with any test plant.

\subsection{Seed sterilization and inoculation on media}

Seeds were inoculated on media after sterilization (using 1.6\% dichloroisocyanuric acid) and being soaked in water for one hour at room temperature. Contaminated seeds were gradually excluded from the experiment until the contaminations stopped. There were $23.7 \%$ contaminated Petri dishes with seeds in total, of which $22.3 \%$ were with mould, $66.7 \%$ with bacteria and $11.1 \%$ with a combination of mould and bacteria. Neither crossing combination was completely lost due to contamination, only seeds from one Petri dish, i.e., one repeat was lost.

A combination of $1.6 \%$ dichloroisocyanuric acid and 10 minutes of sterilization was very effective. With the use of a centrifuge, the surface tension of seeds was neutralized, which enabled the sterilization solution to access the surface of seeds, thus adding to the effectiveness of sterilization. It is also possible to remove the sterilization solution much more easily with a micropipette, while seeds were collected at the bottom of the microcentrifuge tubes, as previously reported also by Jevšnik (2002). The combination of the selected concentration of sterilization solution, sterilization agent and sterilization time beneficially affected seed sterilization, since $76.3 \%$ of the seed combinations remained uncontaminated. Hicks (2000) recommended calcium hypochlorite as the best disinfecting agent for orchid seeds but notes more than $50 \%$ contamination after such sterilization.

\subsection{Morphological stages}

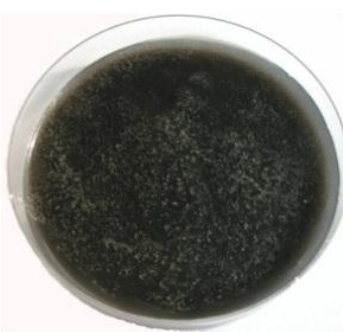

A
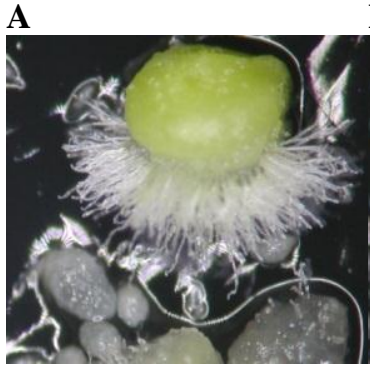

D

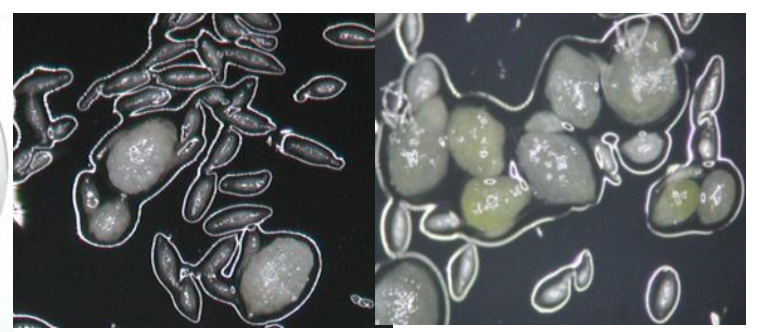

C

B C

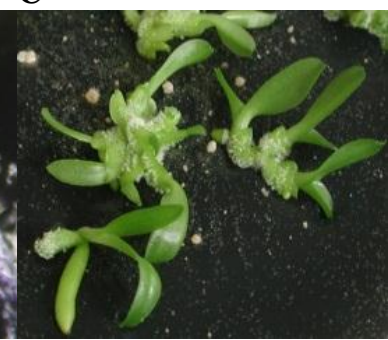

F

Fig. 1: In vitro germination, growth and development of Phalaenopsis hybrids: A - sterilized seeds inoculated on media; B - 6 days after inoculation the majority of seeds were unswollen, only a few seeds had developed into protocorms; C - 22 days after inoculation some white protocorms had started to produce chlorophyll; D - 40 days after inoculation green protocorms had formed rhizoids; E - 65 days after inoculation the first leaves had appeared; F - 80 days after inoculation there were plants with 1 - 2 leaves and one or more roots. 
The beginning of germination was considered to be when embryos started to swell and to grow, which was clearly visible through transparent testa using a stereomicroscope. That stage was already noticeable after two days of inoculation of seeds on media, regardless of the cross combination. Bhattacharjee et al. (1999) reported seed swelling only 14 days after inoculation but those seeds had not previously been soaked. In our case, seeds were soaked for one hour in water prior to inoculation. In addition, media for inoculation and the microclimate in the Petri dish had a high relative humidity. Protocorms already started to form 6 days after inoculation and, after 20 days, chlorophyll in the protocorms started to multiply. In the period up to 40 days following inoculation, rhizoids and the beginnings of the first leaves were seen.

A lot of green protocorms with rhizoids and the beginnings of leaves started to decay after 40 days after inoculation. The reason for browning may have been an unsuitable media composition, an excess or deficit of a particular element. It is probably due to the use of full concentration P1056 media, which contained too many nutrients for normal development. Protocorms should probably be sub-cultivated on half strength media. It is known from the literature that many orchid species germinate well on less complex media, i.e., with fewer nutrients that are not required for further growth and development (Rasmussen, 1995). Protocorms that remained vital developed leaves and roots very quickly on this media.

Sixty-five days after inoculation, most protocorms had second leaves and the beginnings of roots. In the following 14 days (80 days after inoculation), plants with two leaves and one to two roots appeared. Hinnen et al. (1989) noted the importance of nitrogen in media, which influences growth. They also mentioned that strong shoot growth reflects weaker root development, which they define as the ratio shoot/roots. Media P1056 contains nitrogen in the form of ammonium nitrate $\left(\mathrm{NH}_{4} \mathrm{NO}_{3}\right)$ and potassium nitrate $\left(\mathrm{KNO}_{3}\right)$. A nitrate form of nitrogen is more accessible to a plant, but only when the plant reaches the developmental stage where enzymes started to function. The addition of an ammonium form of nitrogen as well is therefore recommended (Hinnen et al., 1989).

The first plants started to appear 80 days after inoculation of the seeds on media. The development of Phalaenopsis seedlings in vitro can take from 50 to 724 days and for further in vivo development, another 4.2 to 31.5 months. Seedlings can flower for the first time after one year or after 11 years, depending on the species (Arditti, 1992).

The main problem in developing new varieties is the long time period needed for the first flowering induction. Selection of new varieties is based on the color and shape of the flowers and it is therefore very important for new plants to flower as soon as possible. It is possible to induce in vitro flowering in vegetatively propagated shoots of Phalaenopsis but flowers are often deformed, although they can indicate an interesting phenotype (Duan and Yazawa, 1995).

\subsection{Percentage of developed protocorms 40 days after inoculation}

The percentage of developed protocorms of all 12 treatments is shown in Figure 2. According to the data, they were transformed with the $\arcsin (\operatorname{sqrt}$ (portion of protocorms)) function. The assumption of the analysis of variance test that variances among treatments are equal was accepted (Levene's test $p=0.3667$ ).

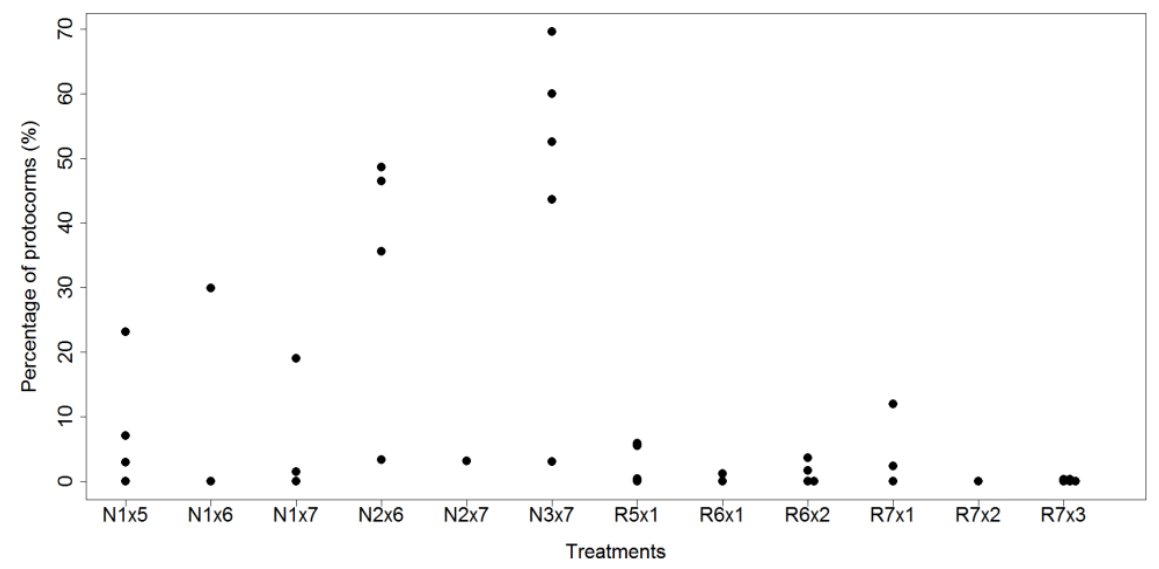

Fig. 2: Percentage of developed protocorms after cross and reciprocal crossing for each repetition of the same cross combination for 6 Phalaenopsis orchids. 
Table 3: Crossing combination of 6 Phalaenopsis orchids and the average of developed protocorms 40 days after inoculation and the percentage of grown plants 80 days after inoculation. Averages of percentages followed by identical letters are not significantly different according to Duncan's multiple-range test $(p<0.001)$.

\begin{tabular}{|c|c|c|c|c|c|c|c|}
\hline \multirow{3}{*}{$\begin{array}{c}\text { Crossing } \\
\mathrm{N}\end{array}$} & \multirow{3}{*}{$\begin{array}{c}\begin{array}{c}\text { Plant } \\
\text { combination }\end{array} \\
3 \circ \times 7 \lesssim\end{array}$} & \multirow{3}{*}{$\begin{array}{c}\begin{array}{c}\text { Flower } \\
\text { size }\end{array} \\
\text { middle } \\
\text { x large }\end{array}$} & \multirow{3}{*}{$\begin{array}{c}\begin{array}{c}\text { Number } \\
\text { of } \\
\text { repeti- } \\
\text { tions }\end{array} \\
5\end{array}$} & \multirow{3}{*}{$\begin{array}{c}\begin{array}{c}\text { Standard } \\
\text { error of } \\
\text { mean } \\
(\%)\end{array} \\
0.9\end{array}$} & \multicolumn{3}{|c|}{$\begin{array}{c}\text { Number of days after } \\
\text { seed inoculation }\end{array}$} \\
\hline & & & & & \multicolumn{2}{|c|}{$\begin{array}{c}40 \text { days - } \\
\text { average } \\
\text { percentage } \\
\text { of } \\
\text { protocorms }\end{array}$} & \multirow{2}{*}{$\begin{array}{c}80 \text { days } \\
\begin{array}{c}\% \text { of } \\
\text { plants }\end{array} \\
2.8\end{array}$} \\
\hline & & & & & 43.1 & $\mathrm{a}$ & \\
\hline $\mathrm{N}$ & $2+\times 6{ }^{\lambda}$ & $\begin{array}{l}\text { small } \mathrm{x} \\
\text { large }\end{array}$ & 4 & 1.1 & 30.6 & $a b$ & 1.4 \\
\hline $\mathrm{N}$ & $1 q \times 6 \curvearrowright$ & $\begin{array}{l}\text { small } \mathrm{x} \\
\text { large }\end{array}$ & 2 & 2.3 & 8.1 & $\mathrm{bc}$ & 1.3 \\
\hline $\mathrm{N}$ & $1+\times 5{ }^{\lambda}$ & $\begin{array}{c}\text { small } \mathrm{x} \\
\text { large }\end{array}$ & 4 & 1.1 & 5.5 & $\mathrm{bc}$ & 1.2 \\
\hline $\mathrm{N}$ & $19 \times 7 \delta$ & $\begin{array}{l}\text { small } \mathrm{x} \\
\text { large }\end{array}$ & 3 & 1.5 & 3.6 & $\mathrm{c}$ & 0.8 \\
\hline $\mathrm{R}$ & $7 q \times 1{ }^{\wedge}$ & $\begin{array}{c}\text { large } \mathrm{x} \\
\text { small }\end{array}$ & 3 & 1.5 & 2.9 & $\mathrm{c}$ & 0.7 \\
\hline $\mathrm{R}$ & 5 우 $\times 1{ }^{\lambda}$ & $\begin{array}{c}\text { large } \mathrm{x} \\
\text { small }\end{array}$ & 4 & 1.1 & 1.8 & $\mathrm{c}$ & 0.8 \\
\hline $\mathrm{R}$ & $69 \times 2 \widehat{\jmath}$ & $\begin{array}{c}\text { large } \mathrm{x} \\
\text { small }\end{array}$ & 4 & 1.1 & 0.7 & $\mathrm{c}$ & 0.5 \\
\hline $\mathrm{R}$ & $69+1 \delta$ & $\begin{array}{c}\text { large } \mathrm{x} \\
\text { small }\end{array}$ & 2 & 2.3 & 0.3 & $\mathrm{c}$ & 0.5 \\
\hline $\mathrm{R}$ & $7 ㅇ ㅜ 33$ & $\begin{array}{l}\text { large } x \\
\text { middle }\end{array}$ & 5 & 0.9 & 0 & $\mathrm{c}$ & 0 \\
\hline
\end{tabular}

Legend: $\mathrm{N}$ - cross crossing, $\mathrm{R}$ - reciprocal crossing, $\uparrow$ - female plant, $\hat{O}$ - male plant

Analysis of variance showed that there are statistically significant differences between the average percentage of developed protocorms $(p=0.0009)$ among treatments (Table 3).

The largest average of protocorms $(43.1 \%)$ developed in cross crossing of plants $\mathrm{N} 3 \times 7$, which statistically significantly differed from all other crossing combinations, except cross crossing N2x6 (30.6\%). There are no statistically significant differences between crossings $\mathrm{N} 2 \times 6, \mathrm{~N} 1 \times 6(8.1 \%)$ and $\mathrm{N} 1 \times 5(5.5 \%)$ and there are no statistically significant differences among all of the remaining crossings. There is an overlap of groups among combinations of cross crossing with small flowers $\mathrm{x}$ big flowers and reciprocal crossing of big flowers x small flowers (Table 3).

There is a statistically significant difference between cross crossing of plants N2x6 and reciprocal crossing of $\mathrm{R} 6 \times 2$, in which a higher proportion of protocorms developed in cross crossing $\mathrm{N} 2 \times 6$ (30.6\%) compared to reciprocal crossing R6x2 $(0.7 \%)$. Statistically significant differences in the average number of developed protocorms also appeared between cross crossing $\mathrm{N} 3 \times 7$ and reciprocal crossing $\mathrm{R} 7 \times 3$. In reciprocal crossing $\mathrm{R} 7 \mathrm{x} 3$, protocorms did not develop at all while the proportion of developed protocorms was the highest in cross crossing $(43.1 \%)$.

In general, more protocorms developed in cross combination when plant with smaller flowers was a female plant than when it was a male plant (Table 3).

Plant no. 4 was not compatible with any test plants. Seed capsules without seeds developed when plant 4 was a femaleplant and flowers just fell off when plant 4 was a male plant. Hicks (2000) notes that it is very important how the parental plants are chosen. If there are two plants, one with bigger flowers than the other, the plant with bigger flowers should be used as the pollen donor. The reason for this is that germinating pollen does not always develop a long enough pollen tube, capable of reaching the ovarium of the host plant. In our case, plant no. 4 had slightly smaller flowers than all other plants. In addition, it had green-yellow flowers, 
which are usually poorly compatible in crossing, as was confirmed in our case.

\section{ACKNOWLEDGEMENT}

Operation part financed by the European Union, European Social Fund.

\section{REFERENCES}

Arditti, J. 1992. Fundamentals of Orchid Biology. New York, Jihn Wiley \& Sons, 712 p.

Bhattacharjee, S., Khan, H.A., Reddy, P.V. 1999. In vitro Germination of Phalaenopsis Hybrid Seed. Seed research 27: 11-13.

Christenson, E.A. 2001. Phalaenopsis, A Monograph. Portland, Oregon, Timber Press, 330 p.

Duan, J.X., Yazawa, S. 1995. Floral induction and development in Phalaenopsis in vitro. Plant Cell, Tissue and Organ Culture 43: 71-74.

FloraHolland2010. http://www.floraholland.com/nl/overfloraholland/Cooper atie/Documents/Kengetallen\%20EN\%202010.pdf.

Hicks, A.J. 2000. Asymbiotic technique of orchid seed germination. Chandler, The Orchid Seedbank Project, $134 \mathrm{p}$.

Hinnen, M.G.J., Pierik, R.L.M., Bronsema, F.B.F. 1989. The influence of macronutrients and Some Other Factors on Growth of Phalaenopsis hybrid seedlings in vitro. Scientia Horticulturae 41:105-116.
Jevšnik, T. 2002. Asimbiotsko razmnoževanje tropskih orhidej. Diplomsko delo. Biotehniška fakulteta, Odd.za agronomijo, $64 \mathrm{p}$.

R (R Development Core Team (2011). R: A language and environment for statistical computing. R Foundation for Statistical Computing, Vienna, Austria. ISBN 3-90005107-0, URL http://www.R-project.org/.).

Royal Horticultural Society, 2010. http://www.rhs.org.uk/Plants/RHS-Publications/Orchidhybrid-lists

Schwallier, R., Bhoopalan, V., Blackman, S. 2011. The influence of seed maturation on desiccation tolerance in Phalaenopsis anabilis hybrids. Scientia Horticulturae 128: 136-140.

Tang, C.Y., Chen, W.H. 2007. Breeding and Development of New Varieties in Phalaenopsis In: Chen, W.H., Chen, H.H. (Editors): Orchids Biotechnology. Singapore, World Scientific Publishing Co. Pte. Ltd. 1-22.

Wing Yam, T., Arditti, J. 2009. History of orchid propagation: a mirror of the history of biotechnology. Plant Biotechnol. Rep., 3:1-56. 